\title{
Editorial
}

\section{Publications in Cell Death: the golden age}

\author{
G Melino $^{*, 1}$, RA Knight ${ }^{2}$ and DR Green ${ }^{3}$ \\ 1 Biochemistry Lab, IDI-IRCCS, University Tor Vergata, 00133 Rome, Italy \\ 2 Imperial College, National Heart \& Lung Inst, Emmanuel Kay Bdg, London SW3 \\ 6LR, UK \\ ${ }^{3}$ La Jolla Institute for Allergy and Immunology, San Diego, CA 92121, USA \\ * Corresponding author: E-mail: gerry.melino@uniroma2.it
}

Apoptosis or Programmed Cell Death has been among the fastest growing fields in the last decade. Indeed, the number of publications has increased from fewer than 100 in 1990 to over 13000 in 2000, see Figure 1.

The total number of publications over this decade to date is 55074 , and a log scale has been used to demonstrate that the current trend seems to be reaching a plateau (Figure 1). The current number of papers per year (13 000) corresponds to about $1.8 \%$ of all papers published in life sciences, an extraordinary proportion. Is this plateau real and does it predict a subsequent decrease? More importantly, to what extent does this reflect a true plateau of the importance with which scientists view cell death or does it merely represent an increase in the quality of published manuscripts? In general, $40 \%$ of all publications receive no citations in the subsequent literature, and two thirds of them receive less than two citations. This proportion is similar in the field of cell death. ${ }^{1}$ Nevertheless, the immense expansion over the last decade is witness to the perceived relevance of the area, and the corresponding spread into the understanding of molecular mechanisms together with its relationships with other relevant areas of biology including practical medical applications.

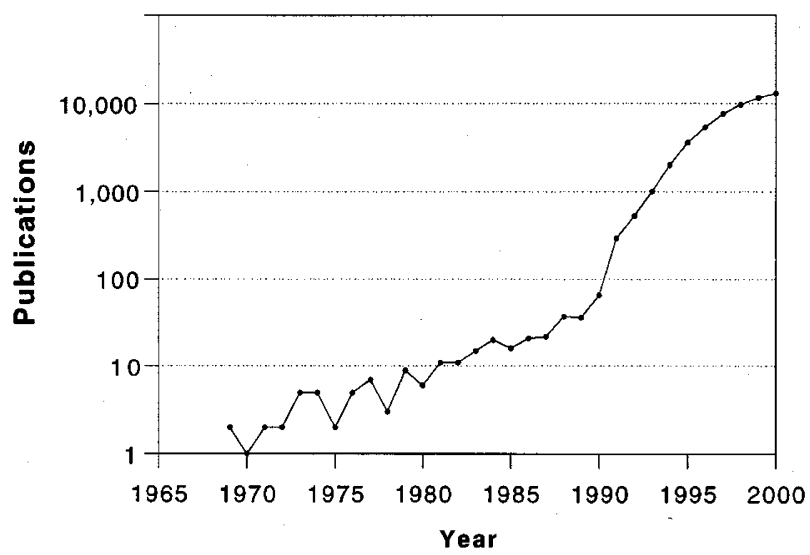

Figure 1 Number of publications per year on 'apoptosis' or 'cell death'. The value for the year $2000(13052)$ has been predicted based on the first 38 weeks (9538). Data are from Web of Science-ISI, Philadelphia, PA (2000)
Out of $10^{14}$ cells in the human body, about $10^{7}$ are now known to undergo apoptosis daily. This awareness is reflected in the shift in regard of apoptosis from a curiosity (in the 1980s) to a highly relevant biological event, whose inappropriate regulation leads to an array of pathologies. The 'Golden Age' of the Nineties has left all of us with a detailed knowledge of molecular mechanisms, for example, the families of $\mathrm{Bcl}-2$, caspases, DNA damage pathways, signaling cascades, receptor regulation, cell cycle, mitochondria and regulation of cell clearance. This leap in academic understanding has expanded into more practical areas such as the role of apoptosis in development and in pathologies of the neuronal and immune systems. Further

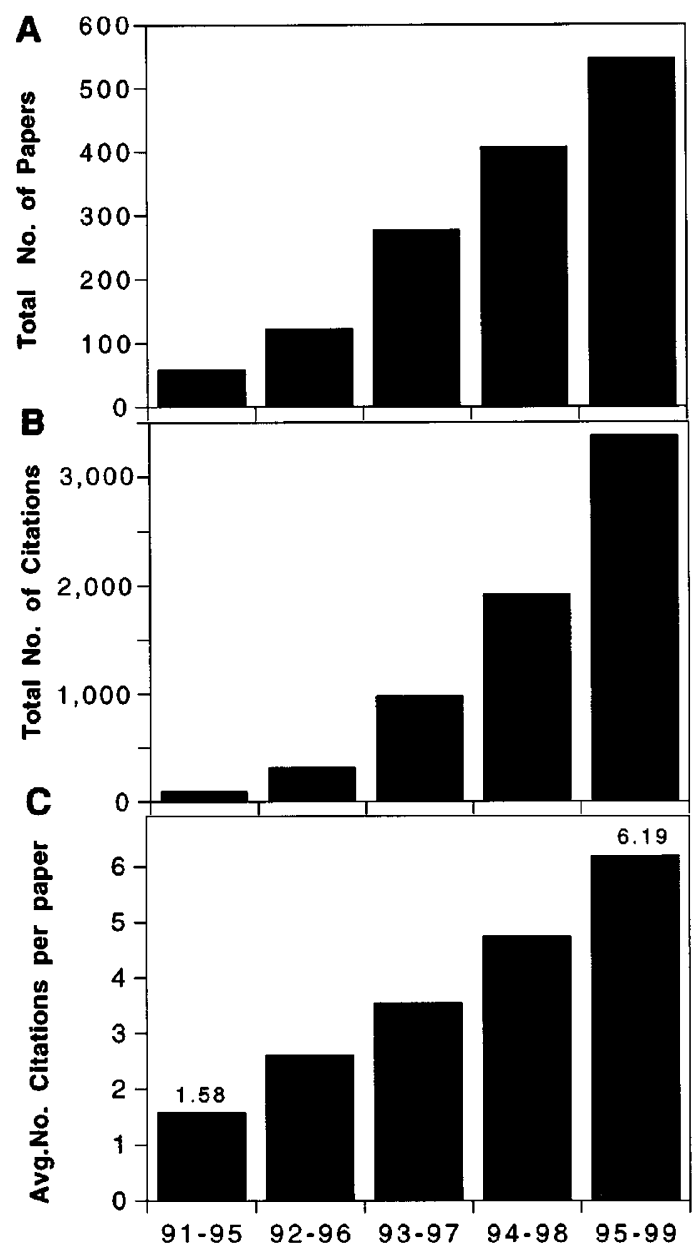

Figure 2 Performance of Cell Death and Differentiation on a 5 -year basis. (A) Total number of papers published every 5 years. (B) Total number of citations every 5 years. (C) Average number of citations per paper on a 5 -year basis. Data are from ISI, Philadelphia, PA (2000) 
detailed description of these aspects is to be found in more specialized reviews (see for reviews ${ }^{2-11}$ ).

Cell Death and Differentiation (CDD) was started in 1994 to act as a forum for this new field. Figures 2 and 3 show how the journal has gradually but continuously increased its number of papers, total number of citations, and most

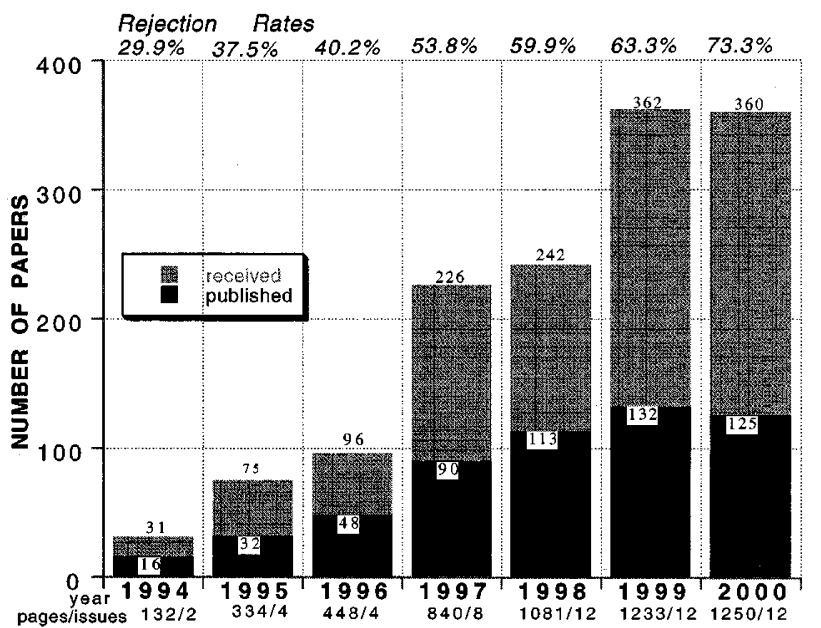

Figure 3 Number of papers received (lower columns, in black) and published (upper columns, in grey) in Cell Death and Differentiation every year. The figure shows only papers, not added material (e.g. editorial, meeting reports, book reviews, letters). The rejection rate is based on final decision, not on the first evaluation. The rejection rate is also based on the year, even though material received in autumn, and often in summer, ends in the following year. The value for the year 2000 has been predicted based on the first 40 weeks

Table 1 Citation of Cell Death and Differentiation

\begin{tabular}{|c|c|c|c|}
\hline \multicolumn{4}{|c|}{ A. Journals cited in CDD } \\
\hline Rank & Journal & Cites & Cites/paper \\
\hline 1. & Cell & 1923 & 3.76 \\
\hline 2. & J Biol Chem & 1785 & 1.81 \\
\hline 3. & Nature & 1341 & 3.13 \\
\hline 4. & Science & 1224 & 2.94 \\
\hline 5. & PNAS & 1193 & 1.73 \\
\hline 6. & Cancer Res & 660 & 1.80 \\
\hline 7. & EMBO J & 658 & 2.33 \\
\hline 8. & J Immunol & 587 & 1.75 \\
\hline 9. & $\mathrm{~J}$ Exp Med & 495 & 2.55 \\
\hline 10. & CDD & 490 & 2.47 \\
\hline \multicolumn{4}{|c|}{ B. Journals (other than CDD) that have cited CDD } \\
\hline Rank & Journal & Papers* & \\
\hline 1. & J Biol Chem & 117 & \\
\hline 2. & BBRC & 58 & \\
\hline 3. & Exp Cell Res & 51 & \\
\hline 4. & Oncogene & 50 & \\
\hline 5. & FEBS Lett & 46 & \\
\hline 6. & Cancer Res & 42 & \\
\hline 7. & Blood & 32 & \\
\hline 8. & J Immunol & 30 & \\
\hline 9. & PNAS & 30 & \\
\hline 10. & EMBO J & 26 & \\
\hline
\end{tabular}

*Each paper contains more than one citation. Data are from ISI, Philadelphia, PA (2000) importantly its quality over time, reaching 6.19 citations per paper (Figure 2C). The journal is cited by, and cites, all relevant and respected scientific media (Table 1), with some CDD papers achieving impressive numbers of citations/paper (Table 2). Despite some technical difficulties, such as for example a late entry into PubMed (see Table 3), the journal is now a major reference for its field. This has been achieved only through synergistic efforts between all editors and the publisher, to whom CDD is greatly indebted. The plan for the future aims to strengthen further the role of Cell Death and Differentiation in the scientific community.

For this coming year the journal will improve its organization. First, the Editorial Board will have new members. We therefore welcome J Abrams (US), S Lipton (US), M Peter (US), D Altieri (US), H Ichijo (J), M Naito (J), M Miura (J), RC Bleackley (CAN) and JC Martinou (CH). Special thanks goes to those editors who have left the journal this year, as part of the normal rotation which allows for the introduction of new blood. As in previous years, collaboration with ex-editors will actively continue but on a less formal level. Second, a new Editorial Office will be opened in Tokyo, and will include both Japanese and Australian Editors. Third, the journal has recently opened a new section for airing discussion and comment of topical issues. Fourth, as every year, the journal will strive to continue the improvement at both the scientific and editorial levels. All three offices will further improve speed and homogeneity of decision, while the publisher will continue to improve marketing and develop new media technologies. Finally, the journal will continue to publish parallel reviews aimed at summarizing the current state of knowledge. Some of the recent areas covered include mitochondria

Table 2 Citation of papers published in Cell Death and Differentiation

\begin{tabular}{llcc}
\hline Rank & Author & Cites & Cites/paper \\
\hline 1. & Reed JC & 173 & 12.36 \\
2. & Kumar S & 140 & 15.56 \\
3. & Orrenius S & 121 & 7.12 \\
4. & Green DR & 119 & 10.82 \\
5. & Lavin MF & 115 & 23.00 \\
6. & Krammer PH & 112 & 11.20 \\
7. & Peter ME & 89 & 14.83 \\
8. & Tilly JL & 85 & 17.00 \\
9. & Helbardt S & 78 & 39.00 \\
10. & Perez & 74 & 18.50 \\
11. & Martin SJ & 72 & 12.00 \\
12. & Sikorska M & 72 & 18.00 \\
13. & Walker PR & 72 & 18.00 \\
14. & Briehl MM & 68 & 22.67 \\
15. & Gougeon ML & 66 & 22.00 \\
16. & Krajewski S & 66 & 13.20 \\
17. & Kroemer G & 65 & 21.67 \\
18. & Cotter TG & 63 & 7.88 \\
19. & McGahon AJ & 63 & 15.75 \\
20. & Kolesnick RN & 62 & 31.00 \\
21. & Lockshin RA & 61 & 12.20 \\
22. & Chinnaiy AM & 59 & 29.50 \\
23. & Dixit VM & 59 & 59.00 \\
24. & Kischekl FC & 59 & 59.00 \\
25. & Nobel I & 59 & 29.50 \\
\hline & & & \\
\hline
\end{tabular}

Data are from ISI, Philadelphia, PA (2000) 
Table 3 Most cited papers in Cell Death and Differentiation

\begin{tabular}{|c|c|c|c|c|c|}
\hline \multirow[b]{2}{*}{ Rank } & \multicolumn{2}{|c|}{ Cites } & \multirow[b]{2}{*}{ Author } & \multirow[b]{2}{*}{ Ref } & \multirow[b]{2}{*}{ Title } \\
\hline & Real & Expected & & & \\
\hline 1. & 104 & 22.5 & Kumar S & 96. $3: 255$ & The ICE family of cyst \\
\hline 2. & 63 & 16.6 & Kroemer G & 87. $4: 443$ & Mitochondrial implicat \\
\hline 3. & 59 & 22.5 & Peter ME & 96. 3:161 & CD95 assoc \\
\hline 3. & 59 & 22.5 & Slater AFG & 96. 3:57 & Intracellular redox ch \\
\hline 5. & 53 & 20.6 & Walker PR & 95. $2: 97$ & Degradation of chromatin \\
\hline 6. & 48 & 20.6 & Zakeri Z & 95. $2: 87$ & Cell death programme \\
\hline 7. & 47 & 17.6 & Polakowska RR & 94. 1:19 & Apoptosis: the skin \\
\hline 8. & 42 & 22.5 & Dowson VL & 96. $3: 71$ & Free radicals and neuro \\
\hline 9. & 40 & 17.6 & Bobrug SE & 95. 2:173 & Biochemical and function \\
\hline 9. & 40 & 20.6 & Gougeon ML & 95. $2: 1$ & Does apoptosis contribute \\
\hline 9. & 40 & 17.6 & Martin SJ & 95. $2: 253$ & Inhibition of ceramide \\
\hline
\end{tabular}

Attention: none of these papers is listed in Medline. Data are from ISI, Philadelphia, PA (2000)

(see for example ${ }^{12-17}$ ), Drosophila apoptosis (see for example ${ }^{18-21}$ ), neurodegeneration (see for example ${ }^{22-24}$ ), the p53 family (see for example $e^{25,26}$ ), and caspases (see for example $27-29)$.

At the beginning of this new millennium, Cell Death and Differentiation would like to take this opportunity to thank sincerely all readers, contributors, editors, assistants and publishers for their time and effort dedicated to making it a success, and looks forward with pleasant anticipation to continuing to improve our positive interaction in the future.

\section{Acknowledgements}

During the preparation of this note, we have enjoyed discussions, reflections, thoughts, and comments (sometimes in a lab or an editorial office, more often sailing in Greece or in front of a beer) with many colleagues, including in particular Mauro Piacentini, Vincenzo De Laurenzi, Penny Lovat, Michael Osuch, Marie-Therese Heemels, Marie McVeigh and Gene Garfield. We would particularly like to thank those who daily help to create Cell Death and Differentiation, Cesare Vongher, Pauline Cripps, Nashita Nanu, Jane Torr and especially Tasmeen Monie who will sadly leave us during the present year. Since it is impossible in such a short note to be comprehensive, our apologies to many colleagues for having failed to cite their contributions.

\section{References}

1. Garfield E and Melino G (1997) The evolution of Cell Death: an analysis from the ISI-Science Citation Index. Cell Death Differ. 4: 352-361

2. Heemels MT (2000) Nature insight apoptosis. Nature 407: 769

3. Hengartner MO (2000) The biochemistry of apoptosis. Nature 407: 770-776

4. Rich T, Allen RL and Wyllie AH (2000) Defying death after DNA damage. Nature 407: $777-783$

5. Savill J and Fadok V (2000) Corpse clearance defines the meaning of cell death. Nature 407: 784-788

6. Krammer PH (2000) CD95's deadly mission in the immune system. Nature 407: $789-795$

7. Meier P, Finch A and Evan G (2000) Apoptosis in development. Nature 407: $796-801$

8. Yuan J and Yankner BA (2000) Apoptosis in the nervous system. Nature 407: $802-809$
9. Nicholson DW (2000) From bench to clinic with apoptosis-based therapeutic agents. Nature 407: 810-816

10. Green DR (2000) Apoptotic pathways: paper wraps stone blunt scissors. Cell 102: $1-4$

11. Lockshin RA, Osborne B and Zakeri Z (2000) Cell death in the third millennium. Cell Death Differ. 7: 2-7

12. Vieira HLA, Haouzi D, El Hamel C, Jacotot E, Belzacq AS, Brenner $C$ and Kroemer G (2000) Permeabilization of the mitochondrial inner membrane during apoptosis. Impact of the adenine nucleotide translocator. Cell Death Differ. 7: $1146-1154$

13. Matsuyama S and Reed JC (2000) Mitochondria-dependent apoptosis and cellular pH regulation. Cell Death Differ. 7: $1155-1165$

14. Korsmeyer SJ, WeiMC, Saito M, Weiler S, Oh KJ and Schlessinger P (2000) Proapoptotic cascade activates BID, which oligomerizes BAK or BAX into pores that result in the release of cytochrome c. Cell Death Differ. 7: 1166-1173

15. Tsujimoto $Y$ and Shimizu S (2000) VDAC regulation by the Bcl-2 family of proteins. Cell Death Differ. 7: 1174-1181

16. Harris $\mathrm{MH}$ and Thompson $\mathrm{CB}(2000)$ The role of $\mathrm{Bcl}-2$ family in the regulation of outer mitochondrial membrane permeability. Cell Death Differ. 7: 1182-1191

17. Von Ahsen O, Waterhouse NJ, Kuwana T, Newmeyer DD and Green DR (2000) The 'harmless' release of cytochrome c. Cell Death Differ. 7: 1192-1199

18. Kumar S and Dousmanis J (2000) The fly caspases. Cell Death Differ. 7: 10391044

19. Bangs $P$, Franc $N$ and White $K$ (2000) Molecular mechanisms of cell death and phagocytosis in Drosophila. Cell Death Differ. 7: 1027-1034

20. Nordstrom W and Abrams JM (2000) Guardian ancestry: fly p53 and damageinducible apoptosis. Cell Death Differ. 7: 1035-1038

21. Hay BA (2000) Understanding IAP function and regulation: a view from Drosophila. Cell Death Differ. 7: 1045-1056

22. Morison RS and Kinoshita $Y(2000)$ The role of $p 53$ in neuronal cell death. Cell Death Differ. 7: 868-879

23. MillerFD, PozniakCD and Walsh GS (2000) Neuronal life and death: an essential role for the p53 family. Cell Death Differ 7: 880-888

24. Aguzzi A and Heppner FL (2000) Pathogenesis of prion diseases: a progress report. Cell Death Differ. 7: 889-902

25. Levrero M, De Laurenzi V, Costanzo A, Gong J, Melino G and Wang JYJ (1999) Structure, function and regulation of p63 and p73. Cell Death Differ. 6: 11461153

26. Lohrum MAE and Vousden KH (1999) Regulation and activation of $p 53$ and its family members. Cell Death Differ. 6: 1162-1168

27. Nicholson DW (1999) Caspases structure, proteolytic substrates, and function during apoptotic cell death. Cell Death Differ 6: 1028-1042

28. Zheng TS, Hunot S, Kuida Kand Flavell RA (1999) Caspase knockouts: matter of life and death. Cell Death Differ. 6: 1043-1053

29. Ekert PG, Silke J and Vaux DL (1999) Caspase inhibitors. Cell Death Differ. 6: $1081-1086$ 